\title{
Managing Financing Risks in Financial Institutions
}

\author{
Azahari Jamaludin (Corresponding author) \\ Universiti Kuala Lumpur Business School \\ 1016 Jalan Sultan Ismail, 50250 Kuala Lumpur, Malaysia
}

Tel: 60-3-2681-7347 E-mail: bjazahari@bis.unikl.edu.my)

\author{
Fais Ahmad \\ College of Business \\ Universiti Utara Malaysia \\ Kedah, Malaysia.
}

Received: Feb. 9, 2013 Accepted: April 9, 2013 Published: June 1, 2013

doi:10.5296/ajfa.v5i1.3233 URL: http://dx.doi.org/10.5296/ajfa.v5i1.3233

\begin{abstract}
The rule of thumb for any business decision is, the higher the risk, the higher the return is and vice versa. Business risk is defined as risk arises out of uncertainty of future events. If these events are undesirable or unfavorable for business, damages and losses may happen. Risk arises because it is impossible to forecast risk in advance whether and to what extent a loss will occur. The importance elements in risk-taking are the hope of success and the fear of failure. That is why it is said that risk is a no-win game. For financial institutions, whether it is conventional bank or Islamic bank, making a right decision to finance is often a difficult task to do and crucial as well. A through and strict risk appraisal of the business must be performed and if they are uncomfortable in taking a certain business risk, normally they will then insist on certain terms and conditions with protection in the form of security and guarantees to overcome the risk identified. The objectives of this research is to understand the various types of business risks attached to different businesses as well as to acknowledge that business risk can be mitigated as well through various methods.
\end{abstract}

Keywords: Business risks, Financial institutions, Shareholders’ risks, Industry risks, Funds diversion risk. 


\section{Introduction}

Business risk arises from many different sub-risks and the assessment will also be dependent on the type and structure of lending and the time horizon of the lending. Therefore, the level of the financial institutions capital at risk will be reflected through the profit (Islamic bank) or interest (conventional bank) spread and/or effective yield of the investing or lending relationship.

\section{Management and Shareholders' Risk}

Character of the management (i.e. integrity and dependability) and capability of the management (i.e. business experience and business connection) are of important in providing the company's direction and strategic plan. Excellent management will be the comfort zone for the banker or investor to even start negotiation on the relationship. The issue of credibility in complying the company law and regulatory requirements, management ability to vision the future, are basic management appraisal/criteria. The management will determine the culture of the organization. Understanding of risk associated with management and/or shareholders capability can be further divided into the following sub-risks: history, management capability, organization and ownership.

\subsection{History}

If there is an adverse change in directorship or management team, investor or banker must try to understand the capability and style of the new management team and be ascertained whether they continue to adopt a conservative or aggressive business style. If the risk assessment on the new management and shareholders indicates that the new business plan will not be successfully implemented, then they might want to consider terminating the relationship. This change in management can be an outcome from mergers and/or acquisitions or from business expansion.

\subsection{Management capability}

Investors/bankers usually take comfort if they lend to people whom they feel can deliver success. Judging the "genuine" management requires interpersonal skill and trade checking and this can be done by asking questions on their attitude towards risk (always be careful with management who are in denial mood). Assessment on capability should include the experience in handling change or adversity. Management skills will affect the achievement of goals on growth, profitability, market share, stock price and dividend.

\subsection{Organization}

Be clear of the size and layers of the management team. The business can be a part of a larger group of companies. As such, the investor or banker will have to be clear of the organizational role and the way the business decision is made. Here, a decision is based on two key influences elements, namely, the corporate culture and the different role of the legal entity or entities.

Corporate culture referred to the flexibility or bureaucracy of workflow and decision-making 
of the organization is part and parcel of the "culture" of the business. Some organization practice the culture of "divide and rule" whilst some organizations practice the teamwork style. Both cultures have their good points provided that the management has a strong hold in maintaining the culture. Divide and rule encourages the employees to strive by bringing in business and revenue, being motivated by the existence of profit sharing incentives. Their incentives correlate positively with the business they bring in. However, this strategy can also back fire due to the possibility of back-stabbing amongst the different business units. On the other hand, the team work culture is also good since all the business unit work towards one common goal, which is the maximization of profit of the whole organization itself. Here, since every employee is a team player, each of them will be on the look out to help his other team members in the event of any difficulties or disruptions in operations for the sake of achieving the goal of the organization. However, be on the look out for any danger signals such as incompetence, fraud, strikes, and poor labor relations

Legal entity/entities, if the business is a part of or a subsidiary or is an associate of a larger group of companies, the investor or banker has to be clear where the management team fits into the larger group of companies. They must be clear of their right under each respective legal entity and study how these entities influence financial decisions of the business. If the management team decision about financing, production, and capital expenditures is made outside the management team which is familiar to the investor or banker, they should further assess the key management team which makes the final decision on these issues. On the other hand, if financial and commercial decisions do not come from the legal entity that borrows, the investor or banker should explore ways where it can control the sources of this decision.

This control can be implemented by incorporating a corporate guarantee, letter of comfort, negative covenants of assets or alternatively, affirmative covenant on majority shareholding of the business. The investor/banker can control the business loan by making sure there is no change in shareholding and control. Sometimes, decisions to borrow or the parking of the loan itself are made at the holding or investment company level. The loan will then either be on-lend to the operating subsidiary or will be used by the holding company for other investments. Therefore, if an investor/banker lends to an investment holding company, they are not in control of the usage of the loan. It is for this reason that they prefer to lend to an operating company which possesses independent capacity to service debt through its own cash flow instead of lending to its parent or its investment holding company. Lending direct will also allow them to closely monitor that the funds are being used for the stated purpose. In the event of a crisis where one legal entity/entities shows losses and is incapable of servicing its debt this can result in a cross default amongst the lenders. The investors/lenders must be guided by the Companies Act 1965 .

\subsection{Ownership}

Be really clear in identifying whether ownership is separate or the same with management. We usually assume that commitment is assured if ownership and management are one and the same. However, there is a possible risk of non-transparency in the business operation. Ownership of public or public-listed companies, which are regulated by regulators, is usually 
more transparent and professionally managed compared to private limited company where the investors or bankers faced the risk of lack of information and non-compliance.

Ownership which is concentrated in a few persons can also be a non-bureaucratic driving force resulting in speedy decision compared to diverse ownership. Diverse ownership may result in shareholders squabbles. In a shareholders squabble which usually involves differences in business direction and personality, it is usually out of the investor's/banker's control to prevent the risk from deteriorating. Therefore, it is advisable to have good security for loans granted against a situation where shareholders are diverse and/or when shareholders are of equal ranking. In case of doubt, insist on assessing the Shareholders Agreement before further assessing the credit.

\section{Industry Risk (Market Risk)}

The industry in which the business competes has to be fully understood by the investor or banker. For example, if they provide long-term financing to the business, the focus will be on the long-term viability of the industry. Since each industry has its own market risks and business cycles. Market risk is simply defined as the risk when there is a sharp change in the value of the product as a result of price movement on the product in the marketplace. It is the risk of changes in demand and supply on the product as a result of variables beyond the control of the business, thereby resulting in drastic change in demand and price of product. For example, the movement of foreign exchange, commodity prices and stock prices in the bourses are market risk which is beyond the control of the business itself.

As for industry, which changes fast in tandem with customer demand, for example information technology, it is important to understand future major trends in the industry that will affect the business. This can be assessed positively or adversely. Industry risk or market risk can be further analyzed into three sub-risks: competition, industry demand risk and external factors.

\subsection{Competition}

Competition can result in a squeeze in market share. Assess whether the business's market share will expand or further diluted. Determine the size and strength of major competitors versus the key success variables of the business. Assess the nature of competition on the scale from perfect to monopoly stake. The type and quality of products play a big role in the success of a business. Assess whether the products and services are unique of uniform, i.e. commodities. In addition, competition can result in a change in market position if the perceived key success variables of the business are not successfully implemented. Loss in market share will result in squeeze in profit margin due to high leverage, low sales or high cost.

\subsection{Industry demand risk}

Each industry has its own variables that create basic demand. For instant, the industry can be financing intensive (leasing and hire-purchase companies), marketing intensive (consumer durable), quality intensive (engineering and electronic products), or service intensive 
(investment banking).

The features of the products and services, therefore, need to change in tandem with the change in consumer demand. Demand risk can also be a result of benefits or hindrances derived from legal or regulatory support, protection, tariffs, and taxes as well as demographic and social factors.

\subsection{External factors}

The effect of inflation on the industry's cycle, political instability, war, electricity or power supply/disruption or the failure of transport or communication system are also external factors that will affect the industry's strength. In analyzing such factors the investor/banker must ascertain whether insurance can be taken to mitigate such external risks on the industry.

\section{Funds Diversion Risk}

This risk can be interpreted as an internal and external source. It is easier to identify this risk when the business is already an existing client of the investor or banker. If they suspect funds are being diverted to various economic entities or out of the country, they should conduct a due diligence meeting with the business. If it is true, and there is no acceptable explanation, they can request that remedial be done (repayment to the investor or banker) within a reasonable time period. If such remedial is not implemented, they can request to terminate the relationship.

Fund diversion can be done through the following two methods, which are usually considered an acceptable practice by the investor or banker as long as they being notified of such a policy/arrangement: transfer pricing and dividend policy

\subsection{Transfer pricing}

Transfer pricing can happen through the sales or purchase of the business as a result of inter-company sales or purchases within a bigger group. Assuming the flagship of a group of companies is not the borrower itself, the transfer pricing as a result of higher purchase price and/or higher cost of good sold will result in poor profitability for the borrower. Whilst the other economic entity which will be the flagship of the group that sells the product to the borrower, will show good profitability. The investor/banker then might decide to use the flagship entity as the borrowing vehicle instead of the loss-making entity.

\subsection{Dividend policy}

Fund diversion can also be done through generous dividend policy. The banker will have to ascertain whether such generous dividend policy has been consistent. If it is not, investigate on the sudden change in policy because it can be the beginning of a problem at the shareholders' level and the banker-borrower relationship. If much needed funds of the business are siphoned out through dividends, the banker might want to terminate the relationship for fear that the business financial position will be adversely affected.

Internally, at the banker's level - if this is an existing customer's - the bankers can further verify movement of funds on an inter-company basis and check whether it is consistent with 
the banker's understanding of the business. At the same time, knowing that the borrower is part of a large group, a complete understanding of inter-company sales purchases, royalties, management fees, loans, investments or dividend policies, will have to be fully understood before money is lent out.

\section{Regulatory Risk}

Whenever required, the investors or bankers must be thorough and satisfied that all regulatory approvals have been complied with or obtained by the business. In Malaysia, for example, the movement of funds is controlled by Bank Negara Malaysia through the Exchange Control Malaysia (ECM) notices. If a financing involves the company's corporate exercises which, in turn, involve equity restructuring and private debt securities, approvals from regulators like Securities Commission, the Kuala Lumpur Stock Exchange and/or the shareholders must be obtained. Compliance to the Companies Act 1965 is a must.

Government regulations support the profitability of some businesses such as public utilities and entities which rely on tariff walls, taxes, and subsidies. Telephone and electricity monopolies are some examples. The investors/bankers must understand the effect of the regulations and judge how likely the policies are to change and how change would affect the business.

\section{Downside Risk}

Some risks can be mitigated and some cannot be mitigated at all are called downside risks. Downside risk is defined as possible but unlikely. It means identifying possible real world events which could create a loss to the business or general market. For example, the death of the major shareholder can be a downside risk to the credit by virtue that he provides a pivotal role in the success of the business. Alternatively, the crash of the stock exchanges can be the real event for a downside risk to any share margin financing. Here, the crash will result in a massive loss to the general investing community or market itself.

In assessing a business risk, investors or bankers have got to acknowledge the existence of such downside risks although they cannot be totally mitigated. Even with the acknowledgement of the downside risk, they still extend the financing based on the key success variables of the credit or the business itself. All financing activities cannot run away from their respective downside risks. If such a risk cannot be mitigated in totality, the investor or banker usually part mitigates it by taking collateral.

\section{Other Business Risk}

Position risk, concentration risk, performance risk and country risk are other business risks that bankers or investors need to carefully examine.

\subsection{Position risk}

A position is the extent to which a business is exposed to price movement in something they buy, sell, or own. Once you have identified a position and its duration, you can decide how great the potential for adverse market movement over the time in question is. The greater the 
risk, the greater the profit margin required to offset the risk. Taking position can also be seen as over stocking. Once the business position has been identified, two other risks hidden in the business (i.e. concentration risk and performance risk) can be further analyzed.

\subsection{Concentration risk}

A business selling a large portion of its output to one purchaser creates a risk. A single plant or facility has greater risk than one with many free standing plants. Selling one product as opposed to selling a variety of products, although is a monopoly also creates a risk. Purchasing a large portion of raw materials from one supplier creates a risk as well.

\subsection{Performance risk}

A buyer might not want to honor its commitment to pay when it finds out that the goods delivered are substandard. Analyze the technical competency of the business and decide whether it is able to perform to meet its sales commitment, its contracts in hand and deliver them in time and to confirm that the commitments are legally binding.

\subsection{Country Risk}

Country risk arises from uncertainty in the country's direction or probably a lack of permanent leadership. If there is a tussle of power and frequent change in leadership of a country, vague and frequent changes in policies can cause disruption in plans and loss of confidence by investors.

\section{Conclusion}

Risk judgment is the most difficult part of financing assessment because it also involves subjective and qualitative issues. Experience, comprehension of financing analysis techniques and depth of business knowledge will result in a more reliable conclusion. Understanding the major types of business risks that have an impact on financing risk will result in a better and more informed financing decision, notwithstanding that different financing institutions have different financing bias and risk appetites. Therefore, we may find that one banker or investor may reject a financing application from a business whereas another banker or investor may approve the application. Since financing is basically a game at perception risk for each of the bankers or investors, the key risk areas identified should be the same and this is the essence of good credit risk analysis.

\section{References}

Azahari, J., \& Marhaini, I. (2007). Types of Business Risk: In The Investors and Bankers Perspectives. $1^{\text {st }}$ MIIT Mini Seminar at Malaysian Institute of Information Technology (MIIT). $27^{\text {th }}-28^{\text {th }}$ March, 2007, Universiti Kuala Lumpur, Kuala Lumpur, Malaysia.

Bessis, J. (2010). Risk Management in Banking. $3^{\text {rd }}$ Edition, Wiley. Retrieved from www.wiley.com/WileyCDA/WileyTitle/productCd-0470019131.html

Choudhry, M. (2007). Bank Asset and Liability Management: Strategy, Trading, Analysis, Wiley. 
Coleman, T.S. (2011). A Practical Guide to Risk Management. Research Foundation of CFA Institute. Retrieved from www.fhwa.dot.gov/asset/pubs/hif12035.pdf

Crouhy, M., Galai, D., \& Mark, R. (2005). The Essentials of Risk Management. 1st Ed., McGraw-Hill.

from ww.amazon.com/Essentials-Risk-Management-Michel-Crouhy/dp/0071429662

GARP (Global Association of Risk Professionals) (2009). Foundations of Banking Risk: An Overview of Banking, Banking Risks, and Risk-Based Banking Regulation. $1^{\text {st }}$ Edition, Wiley. Retrieved from www.ababj.com/briefing/book-review-foundations-of-banking-risk-an-overview-of-bankingbanking-...

Hull, J.C. (2009). Risk Management and Financial Institutions. $2^{\text {nd }}$ Ed., Englewood Cliffs, NJ: Prentice Hall. Retrieved from onlinelibrary.wiley.com/doi/10.1111/j.1539-6975.2009.01332.x/pdf

Hull, J.C. (2012). Risk Management and Financial Institutions. $3^{\text {rd }}$ Ed., Wiley. Retrieved from onlinelibrary.wiley.com/doi/10.1111/j.1539-6975.2009.01332.x/pdf

Institut Bank-Bank Malaysia (2001). Certified Credit Professional (CCP), Study Guide, Kuala Lumpur, Malaysia: IBBM. Retrieved www.ibbm.org.my/v2/wp-content/uploads/2011/06/IBBM010 06 Sept-Oct.pdf

Jorion, P., \& GARP (Global Association of Risk Professionals) (2010). Financial Risk Manager Handbook. $\quad 6^{\text {th }} \quad$ Ed., Wiley. Retrieved from www.amazon.com/Financial-Manager-Handbook-Second-Edition/dp/047143003X

Malz, A.M. (2011). Financial Risk Management: Models, History, and Institutions. $1^{\text {st }}$ Edition, Wiley. Retrieved from value-at-risk.net/references/

Pritchard, C.L. (2010). Risk Management: Concepts and Guidance. $4^{\text {th }}$ Edition, ESI International. Retrieved from www.amazon.com/Risk-Management-Concepts-Guidance-4th/dp/1890367559

Saunders, A., \& Cornett, M. (2010). Financial Institutions Management: A Risk Management Approach. $\quad 7^{\text {th }} \quad$ Ed., $\quad$ McGraw-Hill/Irwin. $\quad$ Retrieved from www.amazon.com/Financial-Institutions-Management-Mcgraw-Hill-Insurance/dp/00735307 51

Saunders, A. \& Cornett, M. (2007). Financial Institutions Management: A Risk Management Approach with $S \& P$ card. $6^{\text {th }}$ Edition, McGraw-Hill/Irwin. Retrieved from www.amazon.com/Financial-Institutions-Management-Mcgraw-Hill-Insurance/dp/00735307 51

\section{Copyright Disclaimer}

Copyright reserved by the author(s).

This article is an open-access article distributed under the terms and conditions of the Creative Commons Attribution license (http://creativecommons.org/licenses/by/3.0/). 